The University of San Francisco

USF Scholarship: a digital repository @ Gleeson Library |

Geschke Center

Sociology

College of Arts and Sciences

$10-1989$

\title{
Silence, Death and the Invisible Enemy: AIDS Activism and Social Movement "Newness"
}

Joshua Gamson

University of San Francisco, gamson@usfca.edu

Follow this and additional works at: http://repository.usfca.edu/soc

\section{Recommended Citation}

Gamson, Joshua, "Silence, Death and the Invisible Enemy: AIDS Activism and Social Movement "Newness"' (1989). Sociology. Paper 1.

http://repository.usfca.edu/soc/1

This Article is brought to you for free and open access by the College of Arts and Sciences at USF Scholarship: a digital repository @ Gleeson Library | Geschke Center. It has been accepted for inclusion in Sociology by an authorized administrator of USF Scholarship: a digital repository @ Gleeson Library| Geschke Center. For more information, please contact repository@usfca.edu. 


\title{
Silence, Death, and the Invisible Enemy: AIDS Activism and Social Movement "Newness"*
}

\author{
JOSH GAMSON, University of California, Berkeley
}

Examining the dynamics and activities of the AIDS activist movement-here, through an analysis based on a participant-observation study of the AIDS Coalition to Unleash Power (ACT UP) in San Francisco -provides an opportunity to clarify issues on which social movements literature tends to be hazy. ACT UP mixes strategic action and material targets with expressive action and cultural targets; their cultural activity takes the form of boundary-crossing and the contesting of images. They often have diffculty distinguishing their targets, and are of "normalization," with the state gradually less directly involved. This argument not only explains the particulars of ACT UP's activism, but also poses challenges to theorizing on contemporary ("new") social movements.

Shea Stadium is packed. As the Mets play the Astros, New York AIDS activists scream and shout along with the rest of the fans. Their cheers are somewhat unusual: "ACT UP! Fight back! Fight AIDS!" Their banners, unfurled in front of the three sections they bave bought out, shout plays on baseball themes: "No glove, no love," "Don't balk at safer sex," bought out, shout plays on baseball themes. "AIDS is not a ball game." The electronic billboard flashes some of their messages as well.
The action gets wide coverage the following day. Later, in a Newsweek (1988a) article on the activist group ACT UP, a baseball fan complains, "AIDS is a fearful topic. This is totally inappropriate."

The fan is right, on both counts; in fact, I would suggest, he inadvertently sums up the point of the action. He also calls attention to the oddities: Why fight AIDS at a baseball game? Why mix fear and Americana? Who or what is the target here?

Susan Sontag and others have noted that the AIDS epidemic fits quite smoothly into a history of understanding discase through the "usual script" of the plague metaphor: originating from "outside," plagues are visitations on "them," punishments of both individuals and groups, they become stand-ins for deep fears and tools for bringing judgments about social crises. "AIDS," Sontag (1988:89) suggests, "is understood in a premodern way."

Yet the plague of AIDS has brought with it understandings and actions that are hardly "premodern": civil disobcdience at the Food and Drug Administration protesting the sluggish drug approval process, gucrilla theater and "die-ins," infiltrations of political events culminating in the unfurling of banners protesting government inaction, media-gcared "zaps," illegal drug research and sales, pickets and rallies. AIDS has given rise to a social movement. This is not, in fact, part of the usual script.

Perhaps, then, AIDS can be understond as part of a different script as well. Much has been written in the past decade about "new social movements" (NSMs); perhaps AIDS acilvism follows an outline particular to contemporary movements. This classification presents its

* This paper would not have been possible without the thoughtful comments, challenges, and support of Michael Burawoy and Sicven Epstein. I'm also grateful for comments on an earlice version of the article from the members of the UC-Berkeley Participanl-Observation seminar and David Kirp. K.jm Yoss, Tomas Almaguer, Bill Gamson, Zelda Gamson, and the Sorial Problems reviewers. Thanks also to the members of ACT UP/Sar Francisco. Correspondence lo: Department of Soctology, University of California, Berkeley. CA 94720.

SOCIAL PROBIEMS, Vol. 36, No. 4, Ocfober 198: 
own difficulties: social movements literature has a hard time clarifying exactly what is "new" about contemporary social movements and can, through its fuzziness, easily accommodate yet another social movement without shedding new light.

In this paper, I examine AIDS activism-by which I mean an organized "strect" respons to the epidemic - -through the activities of ACT UP (the AIDS Coalition to Unleash Power) most widespread and publicly visible direct-action group.

ACT UP, which began in New York, has chapters in Chicago, Boston, Atlanta, Los Angeles, Houston, Rochester, Madison, Nashville, San Francisco, and a number of other cities. The groups are loosely federated under the umbrella of the AIDS Coalition to Network, Organize and Win (ACT NOW). New York is by far the largest ACT UP, with weekly meeting atiendance in the hundreds and membership estimated at ACT UR, with weekly meeting attendSare smaller. San Francisco, with a membership of over 700, averages 50 people at general meetings. My comparisons between ACT UP in San Francisco and chapters in New York and other cities ar based on a national conference in Washington, DC, internal publications, informal discussion and interviews, and newspaper reports.

Using data from six months of participant-observation research (September 1988 through February 1989) in San Francisco's ACT UP, coupled with local and national internal documents and newspaper writings about the group, I develop an analysis intended both to sharpen focus on the struggle over the meaning of AIDS and to challenge some of the hazy understandings of social movement newness. The analysis here trcats ACT UP not the hazy emplar but rather as an anovement newness. The analysis herc trcats ACT UP not as an exemplar but rather as an anomaly, asking what unique conditions constitute the case and how the case can aid in a reconstruction of existing theory. Micro- and macro-level analyses are linked through seeking out an "explanation for uniqueness" such that "we are compelled to move into the realm of the 'macro' that shapes the 'micro' that we observe in face-to-face interaction" (Burawoy 1989:7)
in the fist parts of

In the first part of the paper I briefly review approaches to contemporary social movements, locating ACT UP within this literature. I then turn to ACT UP's activitics and internal obstacles, looking at their response to the plague script, the alternative scripts they propose and their strategies for doing so, and the difficulties they face in this process. I argue that asking "who is the enemy?" provides a fruitful direction for making sense of these dynamics because ACT UP members often have trouble finding their "enemies" The peper continues with an examination of why this may be so, and what light it my she paper continues movements. Borrowing from Michel Foucault (1979), I turn to an examination of the forms of domination to which ACT UP members respond. I argue that, in addition to visible targets such as government agencics and drug companies, much of what ACT UP is fighting is abstract, disembodied, invisible: control through the creation of abnormality. ained less through direct force or institutionalized delineation of the "normal" and the ing izing" process, taking prominence in a graduat his "normalstate oppresion in state oppression in recent decades. State figures and institutions-- though certainly still decpl involved in this domination-are now less apt to contribute to the production and dissemina tion of labels, making the proccss itself, abstracted, the hazy focus of protestion and disseminatraces how responses to normalization play themselves out in ACT UP activities: activists use the labels to dispute the labels, use their abnormality and lenge the process by which this ine lenge the process by which this identity was and is defined. Finally, I suggest directions this framework provides for analyzing contemporary movements.

\section{The Theoretical Context: What's New?}

Among the shifts provoked by the rise of massive social movements in the 1960 s and 1970s was a rupture in theorizing about social movements. Until that time, the dominant 1970 s was a rupture in theorizing about social moveninstitutional movements as essentially paradigm of collective behavior theor strain and breakdown nonrational or irrational the mold. Neither anomic nor (for example, Smelser 1963). Many 1.960s activists did not fit the mold. Neither anomic nor underprivileged nor responding to crises with beliefs "akin to magical beliefs" (Smeiser 1963.8) they in fact came together largely from the middle class, with concrete goals and 1963:8), they in fact came the predictions of classical social movement theory regardrational calculations of strateger operated had broken down (see Cohen ing who made up social
1985. McAdam 1982).

movements have moved in two In the last two decades, attempts to retheorize social mory accounts for large scale mobimajor directions. North American ralculations by actors, focussing on the varying constraints lizations by emphasizing rational calculations by actors, focussing on the upon which they draw and opportunities in which they operate and he (see McCarthy and Zald 1977, Oberschall 1973, Tily 1978, and Jenkins 1981). This paradigm, directly challenging the assumptions of collective behavior theory, insists on the rationality of diretly chalion. European theorists, on the other hand, have argued that rational-actor mod colective action. Eutely applied to new groups seeking identity and autonomy. The moveeis arc inapprose movement, for example, or ments of the 1960s and their apparent descendants feminist, ccological, or local-autonomy movements-have been taken together by theorists as "new" phenomena to be accounted for; it is their nonrational foct "net the the emphasize as distinctive. They attempt to outline the characteristic that these theories emphasize as dis and to discern the structural shifts that might accoun for new dimensions of activity (see Kitschelt 1985, Cohen 1985, Eder 1985, Habermas 1981 for new dimensions of activity

Offe 1985, and Touraine 1985).

With some exceptions (see, for example, Doug McAdam's 1.982 study of black insurgency), American theory, with its insistence on instrumental rationality, tends to pass over these distinctive characteristics-feminist attention to "consciousness, for ex" (NSMs) direc black and gay "pride"-to which European theories of "new social movements" (NSMs) direc attention. The European isterature, then, in that it attempts to explain these apparently new characteristics found also in AIDS activism, provides the stronger conceptual tools with which to approach ACT UP. Yet what is actually "new" according to European NSM theory is both to approach Astinctive (see Eder 198 disputed and unclear. Most agrce that a midde-class socialing-class movements focussed priand Kreisi 1989); indeed, the fact that NSMs are not working-Class movcthere is clarity and marily on economic distribution seems to be a characteristic on which there is clarity and agreement. From here, the range of characteristics expands and abstracts; NSMs chaim the sphere of 'political action within civil society' as [their] space" (Offe 1985:832); they use differsphere of political actir distrient tactics from their pultural reproduction, social bution" but "the grammat of forms of life, ari33); they "manifest a form of middle-class prointegration and socialization" (Habermas 1981.33), they "Inanifest a form of midece" test which oscillates from moral crusade to political pressure group to social movement "Eder 1985.879). they are "both culturally oriented and involved in structural conflicts" (Touraine 1985:879); they are "both culturally oricalism" that "abandons revolutionary dreams in favor 1985:766), involve a setf-linitiong sock seck to of the idca of structural reform, along whical and cconomic systems" (Cohen 1985:664).

abolish the autonomous functioning of poittical and con

Common to this list is a recognition that the field of operation has shifted, broadly put, to "civil society" and away from the state; that culture has become more of a focal point of activity (through "lifestyle" and "identity" movements, for example); and that this shift has to activity (hrough "lfeste "societal type" to which movements respond and in which they do wih broad changes in the "societal he answer to the question of how new the shift really act. Common to the list is also an unclear anner to he nuestion of how new the shift in itsell is; as Jean Cohen (1985:665) poirts out, the theme of defending civil society does not in insell imply something new-the question "is whether the theme has been connccted to new identi- 
ties, forms of organization, and scenarios of conflict." New social movement theorists-even those like Touraine and Cohen who address these qucstions directly-seem to be unclear what these shifts and changes really are: What exactly is the "cultural field" of "civil society" and what do these movements actually do there? What is it that is different about coneno rary society that accounts for the characteristics of new social movefor rary society that accounts for the characteristics of new social movements? When and how
did these changes take place?

\section{ACT UP as a New Social Movement}

ACT UP provides an opportunity both to examine some of these issues concretely and to offer new hypotheses. The AIDS activist movement appears to share the most basic characte istics of "new social movements": a (broadly) middle-class membership and a mix of instrumental, expressive, and identity-oriented activities. Rather than exclusively orienting itself towards material distribution, ACT UP uscs and targets cultural resources as wcll. What, this examination asks, does ACT UP do on the cultural terrain? What light does their activity shed on the question of "newness"? How can a study of this group contribute to an understandin of shifts in the nature of social movements and in the nature of the social world in which they operate?

The answer begins with the group's overall profile. ACT UP/San Francisco grew out of the 1987 San Francisco AIDS Action Pledge, becoming ACT UP in the fall of that year after New York's ACT UP began to gain recognition. In addition to planned and spontaneous ac tions, the group meets wcekly in a church in the predominantly gay Castro neighborhood CT UP/San Francisco is made up almost exclusively of white gay men and lesbians, mostly in their 20 s and 30 s. The core membership - an informal group of about 25 activists-draws from both established activists (gay rights, Central American politics, etc.) and those newiy politicized by AIDS. ${ }^{1}$ Some, but by no means all, of ACT UP's membership has either tested positive for HIV antibodies or been diagnosed with AIDS. As one member said, "I'm here because I'm angry and I'm tired of seeing my friends die." The membership is typically professional and semi-professional: legal and health care professionals, writers, politica organizers, students, artists with day jobs. ACT UP/New York and ACT UPs in other cities exhibit similar profiles (Green 1989).

Self-defined in their flyers and media kits as "a nonpartisan group of diverse individuals united in anger and committed to direct action to end the AIDS crisis" (ACT UP I988a), ACT UP pushes for greater access to treatments and drugs for AIDS-rclated diseases; culturally sensitive, widely available, and explicit safe-sex education; and wcll-funded research that is "publicly accountable to the communities most affected" (ACT UP 1988a). Moreover the pub pushes for the participation of people with AIDS (PWAs) in these activities (ACT UP 1989) The idea here is to change the distribution of resources and decision-making power; the principle guiding actions is strategic, aimed at affecting policy changes. "People have been fighting for social justice in this country for centurics," says one member (September 1988). "We're going to get aerosol pentamidine la treatment drug for pneumocystis pneumonia] a lot quicker than we're going to get social justice."

ACT UP is also often involved in actions, however, whose primary principle is expressive, They focus inward on "building a unified community" (the gay and lesbian community and, increasingly, a sub-community of PWAs and the HIV-infected), and on the "need to express

1. Unless otherwise noted, quotations and descriptions of actions are drawn from the author's field notes from ties, and other commiltce meetings; ACT NOW AIDS Activism Confercnce, October 8-11. 1988, Washings and activiUP/Sал Fтаncisco actions). Fог a sampling of published reporting on ACT UP, 1989, Linebarger 1989. Tullcr 1988, Ford 1988. Johuson 1988 Okie 1988, Co. seclly and Raine LS News E World Repre the anger and rage that is rightcous and justified" from the community outward. They organthe anger and rage that is rightcous and justified" from the coctivism is ize at times around actions in which AIDS is not the central issue or in which AIDS action the liberation." This incorporated into the project of "ecression, while not excluding older-style strategic action, is orientation towards idchity and cxpents of post-60s social movements.

Most interestingly, bough, one hears and sees in ACT UP a constant reference to theater. ACT UP operates largely by staging events and by carefully constructing and publicizing sym. bols; it attacks the dominant representations of AIDS and of people with AIDS and makes attempts to replace them with alternative representations. At times, ACT UP altacks the repattempts to combined with a direct one on cultural producers and the process of AIDS-image production.

Another action principle weaves through ACT UP. As Newsweek (1988a) puts it, ACT UP has often "deliberately trespassed the bounds of good taste": throwing condoms, necking in public places, speaking explicitly and positively about anal sex, "camping it up" for the televipublic places, shis trespen infitration sion cameras. This trespassing or the Republican national convention, for example, where activ of public and private spaces (the Republican ne ists posing as participants unfurled banners)-both uses and strikes at the cultural field as well. In this case, rather than reacting to images of AIDS, activists use a more general tactic of disturbing "good taste"--and, in a point Newsweek quite characteristically misses, calling at distion to the connection between cultural definitions and responses to AIDS. Boundary tention to the cot that ACT UP operates largely crossing, along with hhcatical and symbar on the cultural fieid where theorists situate new social movements. ${ }^{2}$ If also suggests that an examination of the specific patterns of culturally oriented actions may be especially revealing. By focussing on the cultural activities of AIDS activists as a key distintive element, I by no means want to suggest that this activism is primarily cultural. In fact, treatment issues, nee die-exchange programs, and access to health care, for instance, are all common subjects of dle-exchange programs, and access to haCT UP's peculiarities, I hope to generate possibilities for grounding and developing social movement theory.

\section{ACT UP's Internal Obstacles}

The examination turns, then, to ACT UP's distinctive characteristics. ACT UP's strong intrion various strategies are three fundamental confusions. First, ACT UP's orientation towards theatrics suggests a clear three fundamental confusions. First, ACT UP's orientation towards theatrics suggests a clear delineation of performer from audience, yet actions are often planned by ACT UP members without an articulation of whom they're meant to influence. If one wants to affect an audience-for example, by invoking a symbol whose meaning is taken for granted and then giving it a diffcrent meaning-one clearly necds a conception of who that audience is. In ACT UP planning meetings, there is often an underlying confusion of audiences, and more often the question of audience is simply ignored. When activists in New York infiltrated a Republi. can women's cocktail party and later unfurled banners ("Lesbians for Bush," read one), the response of the cocktail partiers, a defensive singing of "God Bless America" (reported in "Workshop on Creative Actions," ACT NOW Conference, Washington, DC, October 8, 1988), was imponant not for that it showed about the Republicans' AIDS consciousness, which was impordant not for what it showed about came as no surprise. Instead, it was important for what it showcd the activists about their
own power. They wcre, in effect, their own audience, performing for themselves and making

2. By way of comparison, it's important to notice that most AIDS politics does not operate according to this description, but according to a more conventional political model. "Most AlDS politicking," as Dennis Altman (1986:105) de scribes it, "has involved the lobbying of federal, state and local governments.... TThis/ has meant dependence upern professional leaders able to talk the language of politicians and bureaucrats." 
others perform for them. In "brainstorms" for new actions, there is almost never a mention of audience, and action ideas with different audiences proliferate. ACT UP protested Dukakis, for example, with no media coverage, Dukakis nowhere in sight, and no one to witness the protest but passing cars (San Francisco, September 30, 1988). In the meetings I observed, I commonly heard suggestions for actions that bypassed any actual event, heading straight for the at-home audience through "photo opportunities," mixed in with suggestions for actions that almost no one would see. Much of this confusion is exacerbated by an openness of exchange and decentralized decision making born of ACT UP's democratic structure (in San Francisco, decisions are made consensually). The loose organizational structure acts against focussed planning and action. I argue, however, that the roots are deeper.

A second point of confusion is that, while ACT UP professes to be inclusive, and ideas are often brought up that target non-gay aspects of AIDS (issues of concern to intravenous drugusers, for example, or access to health care for those who cannot afford it), there are few signs that ACT UP in fact succeeds at including or actively pursues non-gay members. This does not mean that the membership is exclusively gay men; in fact, a good portion of the activists are women. ${ }^{3}$ The formation of coalitions is sometimes brought up as a good idea--"we need to join with others in solidarity around common suffering and common enemies," said the keynote speaker at the ACT NOW conferencc in October 1988-but generally not effected. Cooperative actions with other groups gênerate little excitement in San Francisco meetings. Actions are aimed mainly at targets with particular relevance to lesbians and gays; there are few black or Hispanic members, gay or straight. Despite the goal of inclusiveness, ACT UP continues to draw from and recreate the white, middle-class gay and lesbian community.

A third and related problem is perhaps even more fundamental: AIDS politics and gay politics stand in tension, simultaneously associated and dissociated. ACT UP is an AIDS activist organization built and run by gay people. Historically, this is neither surprising nor problematic; among the populations first hit hardest by AIDS, gay pcoplc were alone in having an already established tradition and network of political and self-help organizations. Still, this tradition has meant that "AIDS groups have found it very difficult to establish themselves as non-gay, even where they have deliberately presented themselves as such" (Altman 1986:90). AIDS activists find themselves simultaneously attempting to dispel the notion that AIDS is a gay disease (which it is not) whilc, through their activity and leadership, treating AIDS as a gay problem (which, among other things, it is)

While this dilemma is in part due to the course the disease itself took, how it plays itself out in ACT UP is instructive. For some, particularly those members who are not newly politicized, ACT UP is gay politics, pure and simple, a movement continuous with earlier activism. They emphasize the need for "sex positive" safe-sex education, for example, linking AIDS politics to the sexual liberation of earlier gay politics. The main organizer of a Novernber 1988 election night rally in San Francisco's Castro district for the gay community to "Stand Out and Shout" about results envisioned it as a return to the good old days of gay celebration. In planning speakers for the rally, he and others quickly generated a long list of possiblesfrom the gay political community. Herc, AIDS issues often get buried.

For others, it's important to maintain some separation, albeit a blurry one, between the two sets of issues. In New York, for example, when a newspaper calls ACT UP a "gay organization," ACT UP's media committee sends out a "standard letter" correcting the error "Media Workshop" at ACT NOW Conference in Washington, DC, October 8, 1988). The ACT UP

3. Why so many women are attracted to the AIDS movernent is an interesting question to which I've accumulated only brief, speculative answers: some because their friends are dying, sorne becarsse of a history of working in healt politics through women's healh issues. One woman suggested an answer that seers to run deeper and along the lin gay pcople are subject." For her, whilc silonce mighe nor mean literal death, it would mean a symblolic death (not bing allowed to live as "mc") genda when the balance is towards distinctive AIDS politics, often focuses more narrowly agenda, when the bate on prevention and treatment advocacy project which anged that "whether it is an entire fas is they are most Harlem or an HIV + gay man in San Francisco, treatment is ulimately the issue they are most concerned with" (ACT UP 1988b:1). More commonly, though. ACT UP actions don't fall on one side or the other, but combine an active acceptance of the gay-AIDS connection with an active resistance to that connection.

\section{Visible and Invisible Enemies}

Why do these particular confusions occur? They eventually will come to make sense as Why do these three confusions within ACT UP the particularities of ACT Up's actions are ex character, in fact will prove to be core which seem to give its action a somewhat unfCT UP's confusions, and those of social moveelements of the group's being. Explaining ACT UP's confusions, and those of social snovements like it, hinges on the answer to a pivotal question: Who is the enemy? Asking this question of ACT UP, one often finds that the enemies against which their anger and action are question of ACled are cleariliar, and visible: the state and corporations. At other times, though, the enemy is invisible, abstract, disembodied, ubiquitous: it is the very process of "normalizathe enemy is invisible, abstract, disernone except one's own "community" of the de-normaltion" through labelling in which everyone except one's own "commes intermediate enemies appear, the ized (and its supporters) is involved. At still other times, intermediate enem

visible institutors of the less visible process: the media and medical science.

This second enemy forms the basis of my core theoretical claim: that ACT UP is respond ing to a gradual historical shift towards a form of domination in which power is maintained through a normalizing process in which "the whole indefinite domain of the non-conforming is punishable" (Foucaut 1979:178) . Through labelling, or socially organized stigmatization is punishable (Foucaut 1979: behaviors and groups are marke as a technique of power. As Michel Foucault (1979:183) ar gues, individuals are differentiated

in terms of the following overall rule: that the rule be made to function as a minimum threshoid, as an average to be respected or as an optimum towards which one must move. It ... hierarcbizes in terms of values the abilities, the level, the "nature" of individuals. It introduces, through this "valuegiving" measure the constraint of a conformity that must be achieved. Lastly, it traces the limit that will define difference in relation to all other differences, the external frontier of the abnormal.

In this process, the dominator becomes increasingly abstracted and invisible, while the dom:In this process, the dominate (and, importantly, "marked" through stigmatization), becomes nated, emboded and visible fon confronted the focus of atten with a punishment (physical, material) as a mechal.

with the threat of being devalued as abnormal.

These ideas are not incompatible with those put forward by the sociology of deviance and discussions of stigmatization (e.g., Lemert 1967, Goffman 1963), which, of course, call atten tion to the process of labelling and its impact on the "deviant." However, the various forms of labelling theory have also been challenged by collective action since the 1.960s. Those theolabeiling theory have one "becomes deviant," and the defensive reaction of "deviants" to an ries, by studying how one "becomes deviant, and the defensive rearied identities" (Goffman) and "secondary identity defined for them-the "management of spoiled identities" (Gofnan) and "secondary deviation" as a "means of defense" against the "problems created by the societal reaction to primary deviation" (Lemert 1967:17)-are ill-cquipped to explain the organization of the stig prized into social movements. As John Kitsuse (1980:5) argues, the accommodative reac matized into social movence sociology (retreat into a subcuiture, nervously covering up or tions analyzed by devian "account for, nor do they provide for an understanding of, the

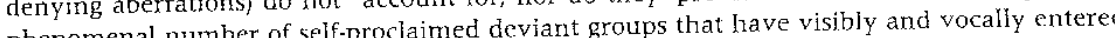


the politics" of recent decades. Earlier theories are hard-pressed to account for historical change, and for the assertive building of collective movements based on self-definitions that reject the dominant definitions. Foucault, on the other hand based on self-definitions that reject the dominant definitions. Foucault, on the other hand, treats pressure for conformity not as a given problem for the "deviant," but as a technique of power with a variable history

Identity strategies are particularly salicnt and problematic within this domination form. When power is effected through categorization, identity is often built on the very categories it resists. ACT UP's expressive actions, in this light, are part of a continuing process of actively forging a gay identity while challenging the process through which it is formed for gay people at a time when the stigma of disease has been linked with the stigma of deviant sexuality. ACT UP members continue to organize around the "deviant" label, attempting to separate label from stigma. Identity-oriented actions accept the labels, and symbolic actions disrupt and resignify them.

Identity actions and representational strategies thus stand in awkward relationship: they are increasingly linked in the attack on the normalization process itself. In a simpler identity politics - in the celebration of gay fiberation, for example-labels are important tools for selfunderstanding. That sort of politics involves what John Kitsuse (1980-9) calls "tertiary deviation," the "confrontation, assessment, and rejection of the negative identity ... and the tevia formation of that identity into a positive or viable selfconception." ACT UP however, push past this "new deviance" to use stigmas and identity markers as tools against the normalization process. The representătion of oneself as abnormal now becomes a tool for disrupting the categorization process; the labels on which group identity is built are used, in a sense, against themseives.

Why, though, is this response to normalizing power coming into its own now? Stigmatization is certainly not new. Foucault, in Discipline and Punish, traces a shift in the eighteenth and nineteenth centuries, a shift that takes place primarily in tcchnologies of control: the risc of surveillance techniques and the constitution of the subject by "experts" and scientific discourse. This shift has arguably solidified in this century in Western societies. Yet while state institutions and actors in the twentieth century certainly have still been involved in the normalization process (as well as in direct repression), thcy have cvidently been less involved in the latter half of this century (or, stated less strongly, less visibly involved). One sees this in the history of civil rights: racism continues while state-sponsored racism and racist policies become less acceptable (see Omi and Winant 1986:89ff). Similarly, state definitions of women's "roics" have been liberalized, as the state has withdrawn somewhat from prescribing "normal" female behavior. One sees this as well in the response to AIDS; the federal government, while conservative or split in its policies, has over time become somewhat more liberal in terms of labelling. Public health officials advertise AIDS as an "equal opportunity destroyer"; the Surgeon General warns against treating AIDS as a gay disease and argues in favor of protections against discrimination; the Presidential Commission calls for "the reaffirmation of compassion, justice, and dignity" and indicts, among other things, "a lack of uniform and strong antidiscrimination laws" (Johnson and Murray 1988). State institutions increasingly refuse to "discriminate," that is, to set policies based on social labcls. As the state becomes less directly involved in normalization, the process itself necessarily becomes more an independent point of attack by the de-normalized and resisted as a process. It is within this overail historical shift in methods of domination, this study proposes, that ACT UP'S social movement activity makes sense.

\section{ACT UP and Normalization}

How does this resistance play itself out? What is the link betwcen enemies and actions? Let's begin with the old forms of domination, which arc very much still at work. The state is certainly involved in the domination of people with AIDS, as it is in the repression of sexual minorities. For example, the Federal Food and Drug Administration approves drugs and has been sluggish in approving AIDS-related drugs; it is perceived as allowing bureaucracy to get in the way of saving or prolonging lives (Newsweek I988b). In October 1988, ACT NOW organ ized a conference, teach-in, rally, and day of civil disobedience in Washington, DC, to "seize control of the FDA" (Okie 1988, Connolly and Raine 1988). The Reagan and Bush administrations have been notoriously inattentive to the AIDS epidemic. Reagan first mentioned AIDS publicly at a time when over 36,000 people had already been diagnosed and over 20,000 had died from the disease. While subsequently calling AIDS "America's number one health problem," the administration consistently avoided initiating a coordinated, adequately financed attack on that problem (see Shilts 1988). Reagan and Bush have become common targets of ACT UP "AIDSgate" signs and t-shirts, of "zaps" of posters charging that "the government has blood on its hands," of disruption and protest during campaign speeches. In this case, specific state institutions and actors are targeted, mostly through conventional protest actions and mediargeared actions. In these cases, it is quite clear who is responsible for needless death and who is controlling resources, and ACT UP functions as a pressure group to protest and effect policy decisions. Here, AIDS politics and gay politics are quite separable and separated.

Similarly, pharmaceutical companies are manifest enemies; they control the price of treatment drugs and make decisions about whether or not to pursue drug development. 'That drug company decisions are guided by considerations of profit (Eigo et al. 1988) is a direct and visible instance of oppression and represents an embodied obstacle to the physical survival of people with AIDS. For example, AZT (azidothymidine, the only drug approved at this writing for treatment of AIDS illnesses) cost $\$ 13,000$ a year in 1987. Again. ACT UP attacks thesc targets with pressure tactics: boycotting AZT manufacturer Burroughs-Wellcome, zapping that company and others with civil disobedience actions, publicizing government-drug company relations (Eigo et al. 1988). In this example, again, the focus is specifically on issues of relevance to all people with AIDS.

Yet AIDS has also been from the outset a stigma, an illness constructed as a marker of homosexuality, drug abuse, moral deficiencies--stigmas added to those of sexual transmission, terminal disease and, for many, skin color. ${ }^{4}$ AIDS has

come to assume all the fcatures of a traditional morality play: images of cancer and death, of blood and semen, of sex and drugs, of morality and retribution. A whole gallery of folk devils have been introduced-the sex-crazed gay, the dirty drug abuser, the filthy whore, the blood drinking voodondriven black ... side by side with a gallery of "innocents"- the hemophiliacs, the blood transfusion "victim," the new born child, even the "hetcrosexual" (Plummer 1988:45)

Associated most commonly with the image of the male homosexual or bisexual AIDS "victim" or "carrier" who is vaguely responsible through deviant behavior for his own demise, AIDS has been appropriated to medicalize moral stances: promiscuity is medically unsafe while monogany is safc; being a member of certain social groups is dangerous to one's health while being a member of the "general population" is dangerous only when the un-general contaminate it. As Simon Watney (1987:126) notes, in AIDS "the categories of health and sickness. . meet with those of sex, and the image of homosexuality is reinscribed with connotations of contagion and disease, a subject for medical attention and medical authority."

The construction and reconstruction of boundaries has been, then, an essential aspect of the story of AIDS. The innocent victim is bounded off from the guilty one, pure blood from contaminated, the general population from the AJDS populations, risk groups from those not

4. The activist response of black communities 10 AIDS has, thotigh, differed greatly from that in gay communitics, and this merits careful examination not allowed for here. The lag in black and Hispanic activism has been attributed by one observer to a combination of lack of material and political resources (minority PWAs are disproportionately lower hes 
at risk. Those who span the boundaries arguably become the most threatening: the promiscuous bisexual, the only one who can "account for and absolve the heterosexual majority of any taint of unlawful desire" (Grover 1987:21) and the prostitute, with her longstanding position as a "vessel" of discase (Grover 1987:25).

Who achieves this demarcation of boundaries? Who has made AIDS mean what it does? Who is the enemy? Two manifest producers of stigmas appear (in addition to certain public figures who disseminate them): the mass media, on whose television screens and newspaper pages the stigmatized are actually visible, and medical science, which translates the labels into risk-group categories. ACT UP thus challenges the medical establishment, largely by undermining the expertise claimed by them. Activists keep up to datc on and publicize underground and foreign treatments (e.g., Eigo et al. 1988), sell illegal treatment drugs publicly, yell the names of known AIDS-illness drugs in front of the FDA ("Show them we know!" the organizer calls). They wear lab coats and prepare a "guerilla slide show". in which they plan to slip slides saying "He's lying" and "This is voodoo epidemiology" into an audio-visual presentation by a health commissioner.

ACT UP also sets up challenges to the media. An ongoing San Francisco battle had ACT UP shutting down production and members negotiating with producers over the script of an NBC drama, "Midnight Caller." In that script a bisexual man with AIDS purposely infects others and is shot and killed in the end by one of his female partners. It was objected to by ACT UP members as playing on "the great fear of the 'killer queer' "5 and implying that, as an ACT UP representative put it, "basically it's justifiable to kill a person with AIDS" (Ford 1988). A similar response has been discussed for the San Francisco filming of Randy Shilts's And the Band Played On, a controversial history of the American AIDS epidemic. The media are usually treated by ACT UP as allies in the public relations operation of garnering coverage. As one New Yorker put it (October 1988), "the media aren't the enemy, the media are manipulated by the enemy, and we can manipulate them too." When actively involved in the labelling of people with AIDS as murderers, however, the media become the enemics to be fought. This ambivalence makes sense: the media, as the institutional mechanism through which normalization is most effectively disseminated, are both a visible enemy and a necessary link to a more abstract form of domination. ${ }^{6}$

The question of who is behind the generation and acceptance of stigmas, though, for the most part doesn't get asked as activists plan and argue, perhaps because the answer is experienced daily: everyone and no onc. No one actually does it and everyone participates in ityour family and your neighbors as well as the blatant bigots far away. It's a process that appears usually as natural, as not-a-process.

\section{Playing with Labels, Crossing the Boundaries}

Fighting this largely hidden process calls for different kinds of strategies, mostly in the realm of symbols. Examining the symbolic maneuverings of ACT UP, we can begin to see how fighting the process calls for particular strategies. ACT UP's general strategy is to take a symbol or phrase used to oppress and invert it. For example, ACT UP makes explicit challenges, guided by other AIDS activists and particularly PWAs, on the kind of language used to

5. The figure of the irresponsible killer-victim was popularized by Randy Slilts in the character of Gaetan Dugas, an airline steward Shilts labels "Patient Zero." Shilts charges that Dugas knowingly spread the virus throughout the continent. For a critique or Shilts, see Crimp. 1987b.

6. The mass media clearly play a very central and complex role in contemporary activism (see, for example, Gitlin 1980), an examination of which is unfortunately beyond the scope of this paper. It's quite likely that much of the dense environment this does not explain the content of those symbols, though, nor docs it explain why the media at times become explicit enemies. discuss AIDS. In place of the "AIDS victims" they speak of "people with AIDS" or "peoplc living with AIDS." In place of "risk groups," they insert the category of "risk practices." They living with AIDS. In place of "risk groups," they furids," and they challenge the exclusionary use of "gencral population" (see Grover 1987).

much deeper than speech, however. The visual symbol most widely publicized by American AIDS activists-" "SILENCE=DEATH" written in bold white-on-black publicized by American AIDS activis letters beneath a pink triangle, the Nazi emblem for. Here, ACT UP takes a symbol used to movement-prowdes a snapshor look at this procs. He control over defining a cause of mark people for death and reclains it. They reclaim, in fact, control ove denning a cause of death; the banner connects gay action to gay survival, on the one hand, and homophobia to death from AiDS, on the other. ACT' UP's common death spectacles repeat the inversion. In death from Ain (Giman 1987); it is either a punishment AlDs comme lonely (the image of the withere "k "die in" in abandoned dying), or a weapon (the image of the irresponsible "killer queer"). A die in, "in which activists draw police-style chalk outlines around each other's "dead" bodies, gives death which activists draw se deaths likened to murdcrs, victims another meaning "y seople controlling the definition and cnnot of their own "dicions say, now we forcement of normality. You have told us what our death

who are actually dying will show you what they mean.

A similar shift of responsibility takes place around the symbol of blond. In popular discussions, blood is talked about in terms of "purity and a benevolent medical establishivites working to keep "bad blood" out of the nation's blood supply. In many ACT UP activities, "working to kecp bas on t-shirts (San Francisco, October 3, 1988) or doctor's uniforms (Washing "blood" is splattcred on t-shirts (San Francisco, October it out squirt guns, blood-balloon it onto ton, DC, October 11,1988). Members want to shoot it out of squit guns, washington, DC buildings, write "test this" with it on walls ("Creative Actions" workshop, Washington, DC, October 8,1988 ). Here, on one level, they use the established discourse of purity against its uscrs as an angry weapon: "infected" blood is everywhere. On another lcvel, though, the users as an angry we purity (in which the blood supply is "victimized") to crime (in which frame is shifted from purity (in which the blood supply is vection, but of murder; the activPWAs are victimized). The blood becomes evidence not of infection, but of murder, the activists are blood-splattered victims, as was made explicit in posters originally directed at Mayor Koch in New York and later translated into an indictment of the federal government. "The goverument has blood on its hands," the sign says, "One AIDS death every half hour." Begovertment has bros is the print of a large, bloody hand. In a San Francisco rally against tween the two phrases is the print of a large, bloody hand. In a san Fould have required by Rep. William Dannemeyer's Proposition 102 (October 3, 1988), which would huire testing at the law that doctors report those infected and those "suspected" of infection, require testing at the

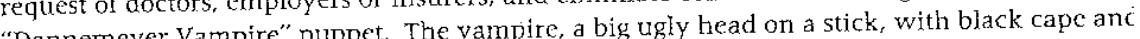
"Dannemeyer Vampire" puppet. The vampire, a big ugly header ACT UH blood pouring from its langs, was stabbed with a stake later in the action. Here, ACs Ut activates another popular code in which blood has meaning-the gore of horror movies-anc reframes blood testing as blood sucking. It's not the blood itself that's monstrous, but thr reframes blow the meaning of blood, ACT UP activists dispute th vampire who wonld take it. By changing the meall attention to the consequences of the labe! "ownership" of blood; more inportantly, they call atentson to labels in the continuation of th of "bad" blood and "purity" and implicate those accepting the labels in the continuation of th AIDS epidemic.

Boundary-crossing, though tactically similar, goes on the offensive while inversions ar Bectacle of infiltration and revelation runs through real a essentilly fantasized ACI UP actions. Miller, of covering the Was pockets of suit jackets, of writing messages on lawns with wed ington monument with a giant condom, of replacing (hetcrosexual) bar ashtrays" wh cor dom-shaped ashtrays. They place stickers saying touched by a Person with Ains" in phon booths and stage a mock presidential inauguration through the San Francisco streets durin 
rush hour (January 1989). The idea, as one activist put it, is to "occupy a space that's not supposed to be yours," to "usurp public spaces." San Francisco's underground graffiti group, specializing in "redccorating" targeted spaces, sums up the principle in its humorous acronym, TANTRUM: Take Action Now to Really Upset the Masses.

The ideas that charge brainstorming sessions and the eventual choices for visual and theatrical activity at actions are not arbitrary. The selections are revealing. Spaces and objects are chosen that are especially American (that is, middle American-lawns, cocktail parties, baseball games, patriotic symbols, suits) and presumably "safe" from the twin "threats" of homosexuality and discase. ACT UP here seizcs control of symbols that traditionally exclude gay people or render them invisible, and take them over, endowing them with messages about AIDS; they reclaim them, as they do the pink triangle, and make them mean differently. In so doing, they attempt to expose the system of domination from which they reclaim meanings and implicate the entire system in the spread of AIDS.

It is important to notice that ACT UP's identity-oriented actions often revolve around boundary-crossing and habel disruption. These are stratcgies for which these mostly white middle-class gay people are particularly equipped, Iargely because their stigma is often invisible unlike, for example, the stigmatized person of color. They can draw on a knowledge of mainstream culture boin of paxticipation rather than exclusion and, thus, a knowledge of how to disrupt it using its own vocabulary. Here the particular cultural resources of ACT UP's membership become important; they are resources that other movements (and gay people from other races or classes) may not have to the same degree or may not be able to use without considerable risk.

Gay campiness, raunchy safe-sex songs in front of the Department of Health and Human Services, straight-looking men in skirts wearing "Fuck Me Safe" t-shirts (Washington, DC, October 1988), lesbians and gay men staging "kiss-ins," a general outrageousness that "kecps the edge"- thesc actions simultaneously accept the gay label, build a positive gay identity, challenge the conventional "deviant" label, connect stigmatization to AIDS deaths, and challenge the very process of categorization. This is the power of the pink triangle an "SLENCE =DEATH"; the building of an identity is linked with the resistance of a stigma as the key to stopping the AIDS epidemic. "We are everywhere," says a sign at a DC ACT NOW rally, a sign common at gay political demonstrations, and the noisy expressions of collective anger and identity add up to the same claim. Here, the gay "we" and the AIDS "we" are melded; the destabilizing effect of the suddenly revealed homosexual is joined with the that suddenly no space is safe from AIDS. A chant at several San Francisco protests captures activists chant, "and we re here to stay." Meaning: we are what you say we are, and we'r not what you say we are. "We're here," they chant, "We're qucer, and we're not going shopping

What exactly is being challenged in these symbolic inversions? Certainly, in symbols like the Dannemeyer vampire and the bloody hand attributed to the government the old and consistent emerny, the statc is mixcd in; but it isn't exclusive. ACT UP distipts symbolic ceprescntation, heeding the call to "campaign and orgaize in order to enter the amphisteater of AIDS commentary effeclively and unapologetically on of AIDS commentary effectively and unapologetically on our own terms" (Watney 1987:54). It does so, moreover, often through symbols that are not ticd to the state but to "mainstream" American culture. In the case of inversions, AIDS and gay labels are not necessarily linked: ny oppressive marker is taken over. In the case of boundary-disruption, AIDS and gay labels are connccted; the fear of gay pcople and the fear of AIDS, now linked in the nom glization process, are used to call attention to themselves. In both cases, the process of stigmizantion by which symbols become markers of abnormality and the basis for decisions about "correcting" the abnormal, is contested.

\section{Strategies and Obstacles Revisited}

The mix of strategies, then, can be seen in terms of the visibility of enemies. More familiar instrumental pressure-group strategies attempt to change the distribution of resources by attacking those visibly controlling distribution. Identity-forming strategies are particularly crucial and problematic when the struggle is in part against a society rather than a visible oppressor. Label disruption-contained in identity-forming strategies, and the core of symbolic strategies-is a particular operation on the cultural field. It is made necessary by a form of domination that operates through abstractions, through symbols that mark off the normal. (I am not suggesting, of course, that these are discrete types in concrete actions; actions are always mixed exactly because the forms of domination are simultaneous.

We can also make sense of ACT UP's internal obstacles through this lens. It's not surprising that the question of audience becomes a difficult one to address. First of all, the audience often is the group itself when identity formation becomes a key part of struggle. Yet at the same time, we have scen that identity struggles involve pushing at the very labels on which they're based, and here the audience is the entire society. Actions are thus often lounded on a confusion of audiences. More commonly, the question of audience is simply lost because the underlying target of action is the normalization process. While it might be more "rational" for ACT UP activists to try to spell out the particular audience each time they design an action, the struggle in which they are involved makes the particularity of an audience diffictilt to see. When stigmatization is being protested, the audience is the undifferentiated society-that is, audience and enemy are lumped together, and neither is concretely graspable.

Understanding that ACT UP is attacking this particular form of domination, we can also see why ACT UP is caught between the association and dissociation of AIDS politics from gay politics. Clearly, PWAs and gay people are both subject to the stigmatization process; this process, as it informs and supports responses to AIDS, has become literally lethal for PWA.s, gay and non-gay, and dangerous for those labelled as "risk group" members, gay men (and often by an odd extension, lesbians), drug users, prostitutes, blacks, and Hispanics. Socially organized Iabels that, before AIDS, were used to oppress, are now joined with the label of "AIDS victim." This form of domination is experienced by ACT' UP members as a continuous one. AIDS is a gay disease because AIDS has been made to attribute viral disease to sexual deviance. Separating AIDS politics from gay politics would be to give up the fight against normalization.

Yet joining the two politics poses the risk of losing the fight in that it confirms the very connection it attempts to dispel. This is a familiar dilemma, as Stcve Epstein (1987:19) point cont and one that is not at all limited to the gay movement: "How do you protest a socially imposed categorization, except by organizing around the category?" Organizing around a re sisted label, in that it involves an initial acceptance of the label (and, in identity-orientec movements, a celebration of it), can tend to reify the label. Identity politics thus contain danger played out here: "If there is perceived to be such a thing as a "homosexual person then it is only a small step to the conclusion that there is such a thing as a 'homosexua discase, itself the peculiar consequence of the "homosexual lifestyle" "Epstein 1987:48). The familiarity of the dilemma, though, should not obscure its significance. This is neither a di Iemma attributable simply to the random course of AIDS nor to mistakes on the part of activ ists, but to the form of domination to which social movements respond.

In this light, it's not surprising that ACT UP has dificulty including non-gays and formin coalitions. In some ways. ACT UP is driven towards inclusiveness since AIDS is affectin other populations and since the fight includes more broad-based struggles over resources. But as we have seen, resistance to labelling involves accepting the label but redefining it, taking over. Group identity actions are bound up with this resistance. This drives ACT UP strongl away from inclusiveness. The difficulty in walking these lines-between confirming and re 
jecting the connection between gay people and AIDS, between including and excluding nongays-is built into the struggle against normalization in which ACT UP is involved.

\section{Bodies and Theories}

I have argued that ACT UP responds to the script of the AIDS plague by undermining that script, resisting the labelling through which contemporary domination is often effectively achieved. This seems to be missed by most observers of AIDS, who interpret the politively AIDS on the model of conventional politics. Randy Shilts's nores the development of grassroots AIDS activism even in its updatig cpilogue, as a particularly vivid case of disputed scripts in Arnes disease as others have case of disputed scripts in American politics in that the epidemic of disease, as others have noted, has occurred simultaneously with an "epidemic of signification"; AIDS exists "at a point where many entrenched problematic and context in which AIDS acquires meaning" (Tres intersect, each with its own illustrates this, treating the struggle over the narratives opened and exposed by AIDS as potentially life-saving.

ACT UP also illustrates major effects of an historical shift. If, as I've proposed in drawing on Foucault, domination has gradually come to operate less in the form of state and tional oppression and more in the form of disembodied and surprising that diseased bodies become a focal point of brocesses, it is hardly enemy becomes increasingly disemoth oppression and resistance. As the the diseacod, increasingly disembodied, the body of the dominated-in this case, primarily the diseased, gay male body-becomes increasingly central. The AIDS epidemic itself fits this process so well as to make it seem almost inevitable: the terror of the discase is that it is an cnemy you cannot see, and, like the labels put to use in normalizing power, it is spread invisibly. AIDS activism in part struggles against this disembodied type of power by giving that body-its death, its blood, its sexuality-new, resistant meanings. The plague script mects here with the script of new social movements.

But what does this tell us about theorizing new social movements? First, it calls into question the value of "newness" as a reified category of analysis. In suggesting that the history of enemies and types of domination is central to understanding ACT UP, this study points to a gradual shift rather than a radical break in movement activity; "newness" militates towards a focus on a moment (the 1960s) rather than a history that reaches back into, for exam ple, the eighteenth and nineteenth centuries (as in the historical transformationto, for examdescribes). It obsures what ma be intructive continuities across timetion that Foucau points towards ways what may be instructive continuities across time. Secondiy, this study UP exemplifies conter that AC analysis demonstrates the insufficiency overstate the case; rather, this simply bealyzing different movements as like phenomen simply because of a shared cultural and identity focus. Operating on the "cultural field" means something more specific than focussing on problems that "deal directly with private Iife" (Touraine 1985:779) or even targeting and using narrative and artistic representation. ACT UP's cultural strategies reclaim and resignify oppressive markers. Orienting actions towards identity formation means something more specific than "defend[ing] spaces for the creation of new identities and solidarities" (Cohen 1985:685). Identity assertions in ACT UP point up boundaries, using the fcar of the abnormal against the fearful These are sp operations that may be shared by other contempor ary specific stigmatization, for example, and which are also in a position to "shements--those subject to Stigmatization, moreover, may take different forms and ment activity. Whether in Shea Stadium of move whom movements are res of enemics to whom movements are responding is a task for analysts of social movements as well as for activists within them.
References

CT UP/San Francisco

1988a "Our goals and demands." Informational flycr.

1988b "The AIDS treatment advocacy project." Proposal drafted for ACT NOW Conference. Scpternber.

1989 "ACT UP PISD caucus." Intormational flyer.

Altman, Dennis

1986 AIDS in the Mind of America. Garden City, NY: Anchor Press/Doubleday.

Burawoy, Michael

1989 "The extended case method." Unpublished manuscript.

Cohen, Jcan L.

1985 "Strategy or identity: new theoretical paradigms and contemporary social movcments." Social Research 52:663-716.

Connolly, Mike and George Raine

1988 "50 AIDS activists arrested at FDA." San Francisco Examiner, October 11:Al.

Crimp, Douglas, ed.

1987a AIDS: Cultural Analysis/Cultural Criticism. Cambridge, MA: MIT Press.

1987b "How to have promiscuity in an epidemic." Pp. 237-71 in Douglas Crimp (ed.), AlDS: Cultural Analysis/Cultural Criticism. Cambridge, MA: MIT Press.

Eder, Klaus

1985 "The 'new social movements': moral crusades, political pressure groups, or social movements?" Social Research 52:869-90.

Eigo, Jim, Mark Harrington, Iris Long, Margaret McCarthy, Stephen Spinella, and Rick Sugden

1988 "FDA action handbook." Unpublished manuscript prepared for October 11 action at the Food and Drug Administration.

Epstein, Steven

1987 "Gay politics, ethnic identity: the limits of social constructionism." Socialist Review 17 Ford, Dave

1988 "'Midnight caller' script provokes gay activists' ire." San Francisco Sentinel, October 21:4-5.

Foucault, Michel

1979 Discipline and Punish. New York: Vintage Books Gilman, Sander

1987 "AIDS and syphilis: the iconography of disease." Pp. 87-107 in Douglas Crimp (ed.), Gitlin, Todd AIDS: Cultural Analysis/CuItural Criticism. Cambridge, MA: MIT Press

1980 The Whole World is Watching: Mass Media in the Making of the New Left. Berkeley. CA: University of California Press.

Goffman, Erving

1963 Stigma: Notes on the Management of Spoiled Identity. Englewood Cliffs, NJ: PrenticeHall, Inc.

Goldstein, Richard

1987 "AIDS and race." Village Voice. March 10:23-30.

Green, Jesse

1989 "Shticks and stones," 7 Days, February 8:21-26.

Grover, Jan Zita

1987 "AIDS: keywords." Pp. 17-30 in Douglas Crimp (ed.), AIDS: Cultural Analysis/Cultural Criticism. Cambridge, MA: MIT Press. Habermas, Jürgen

1981 "Ncw social movements." Telos 49:33-37.

Jenkins, J. Craig

1981 "Sociopolitical movements." Pp. 81-153 in Samuel Long (ed.), Handbook of Political Bchavior. New York: Plenum Press. 


\section{GAMSON}

Johnson, Clarence

1988 "Gays attack KRON building." San Francisco Chronicle, December 12:A2.

Johnson, Diane and John F. Murray

1988 "AIDS without end." New York Revicw of Books. August 18:57-63.

Kitschelt, Herbert

1985 "New social movements in West Germany and the United States." Political Power and Kitsuse, John I.

1980 "Coming out all over: deviants and the politics of social problems." Social Problems 28:113.

Kreisi, Hanspete

1989 "New social movements and the new class in the Netherlands." American Journal of Sociology 94:1078-1116.

Lemert, Edwin

1967 Human Deviance, Social Problems, and Social Control. Englewood Cliffs, NJ: PrenticeHall, Inc

Lincbarger, Charle

1989 "All the rage: angry AIDS activists pump up the volume on deaf policy-makers." San MicAdam, Doug Francisco Sentinel, February 23:3-5.

1982 Political Process and the Development of Black Insurgency 1930-1970. Chicago: University of Chicago Press.

McCarthy, John and Mayer ZaId

1977 "Resource mobilization and social movements: a partial theory." American Journal of Sociology 82:1212-40.

Morgan, Thomas

1988 "AIDS protesters tempcr their tactics as a way to reach the mainstream." New York

Newsweek Times. July 22:A12

1988a "Acting up to fight AIDS." June 6:42.

1988b "The drug-approval dilemma." November 14:63.

Oberschall, Anthony

1973 Social Conflict and Social Movements. Englewood Cliffs, NJ: Prentice-Hall

Offe, Claus

1985 "The new social movements: challenging the boundaries of institutional politics." Social Research 52:817-68.

Okie, Susa

1988 "AIDS coalition targets FDA for demonstration." The Washington Post, October 11:A4 mi, Michael, and Howard Winant

1986 Racial Formation in the United States. New York. Routledge and Kcgan Paul. Plummex, Ken

1988 "Organizing AIDS." In Peter Aggleton and Hilary Homans, (eds.), Social Aspects of AIDS. Shilts, Randy London: The Falmer Press.

1988 And the Band Played On: Politics, People and the AIDS Epidcmic. New York: Penguin Smeiser, Neil

1963 Theory of Collective Behavior. New York: The Free Press. Sontag, Susan

1988 "AIDS and its metaphors." New York Review of Books, October 27:89-99.

Tilly, Charles

1978 From Mobilization to Revolution. Reading, MA: Addison-Wesley. Touraine, Alain

1985 "An introduction to the study of social movements." Social Research 52:749-87.
Treichler, Paula A.

1987 "AIDS, homophobia, and biomedical discourse: an epidemic of signification." pp. 31-70 in Dougs Cimp (ed), AIDS: Cultural Analysis/Cultural Criticism. Cambridge, MA: MIT Press.

Tuller, David

David "ADS prow signs of movement's new militancy." San Francisco Chronicic October 27:A4.

U.S. News and World Report

1989 "The artists' diagnosis." March 27:62.70

Watney, Simon

Policing Desire: Pornography, AIDS and the Media. Minneapolis. MN: University of Minnesota Press. 